It is a great pleasure for me to thank my chief, Mr. J. Duff McCulloch, for permission to publish this case and gratefully to acknowledge my indebtedness to Messrs. Rayner for providing the drawing.

\title{
REFERENCES
}

1. Wurdemann.-Injuries of the eye, p. 482, 1912.

Ramsay.-Injuries of the eye, p. 83.

Rust. -Arch. of Ophthal., Vol. XXXVII, 2. 1908.

Ball.-Brit. Jl. of Ophtha!., Vol. XI, 2, p. 73.

Wurdemann.-Injuries of the eye, p. 463, 1912.

Injuries of the eye, p. 452, 1912.

Wood.-System of ophthalmic operations, p. 784.

Fuchs - Textbook of Ophthalmology (Duane), p. 579.

. Israel.-Amer. Jl. of Ophthal., Vol. IX, p. 271, 1926.

10. Benedict. - Proceedings of staff meeting, Mayo clinic, Vol. III, p. : 69, 1928.

\section{MEDIAEVAL OPHTHALMOLOGY IN MESOPOTAMIA}

BY

A. F. Maccallan, C.B.E.

LONDON

"In the name of God, the Compassionate, the Merciful!

" The book of Hunain ibn Is-Haq on the structure of the eye, its diseases and their treatment written in accordance with the opinions of Hippocrates and Galen."

This is the preface to the earliest existing systematic text-book of ophthalmology, which has been translated by Meyerhof of Cairo, and has been published together with the Arabic text by the Government Press, Cairo, 1928.

The history of the discovery of the manuscript is of considerable interest.* When Hirschberg began his investigations of Arabic ophthalmology, with the help of the orientalists Lippert, Mittwoch and Mann, he found Hunain's name frequently mentioned in the old Arabic and Persian text-books on eye diseases as an author of great repute. With admirable philological insight Hirschberg discovered the "Ten Treatises " of Hunain in two Latin translations, one printed at Lyons in 1515, the author being given as Constantinus Africanus, and the other printed at Venice between 1541 and 1625, authorship being attributed to Demetrius, a Sicilian Greek. So both Constantine and Demetrius separately

* MacCallan, "The Birth of Ophthalmology, etc.," Brit. Jl. of Ophthal., Vol. XI, p. $66,1927$. 
had translated the original Arabic of Hunain into Latin and each had described himself as author.

Meyerhof then set himself the task of finding an Arabic MS. of Hunain's original work. At first he was unable to discover this in any of the public libraries of the Occident or of the Orient, but hearing that a private gentleman possessed a collection of ophthalmological manuscripts he obtained facilities for examining them. This Egyptian country gentleman is Taimur Pasha, whose forebears were officials of importance in the reigns of Mohammed Ali Pasha, and of Ismail Pasha. He is a great collector of ancient manuscripts, and has'built for their accommodation in Cairo a private library, where as a serious Arabic scholar he spends most of his time. The thanks of ophthalmologists are due to him for his liberality in giving access to his literary treasures to scholars of all nationalities.

In this library Meyerhof discovered in 1908 an original MS. of Hunain's " Ten Treatises," which had been obtained from Beirut in Syria. Unhappily, it was not complete. In 1925, Meyerhof obtained a catalogue of Arabic manuscripts which had been collected by Gregory IV, the Patriarch of Antioch, and were in a Leningrad library. This catalogue had been published in Leningrad by Professor Krackovski in 1924, and among other important Arabic MSS. referred to the existence of the "Ten Treatises." Through the kind offices of Professor Krackovski, a copy of the MS. was made and sent to Meyerhof in Cairo. It was found to be not quite complete but the gap was partially filled by quotations of the original by an Arabic author which Meyerhof obtained from the Escorial library, in 1928, after having long searched in vain.

Meyerhof took Taimur Pasha's MS. as his basis and corrected from the Leningrad copy, having at his disposal the Latin translations.

\section{History of Hunain}

Abu Zaid Hunain ibn Is-Haq el Ibadi was born at Hira in Mesopotamia in the year A.D. 809. He was the son of a Nestorian Christian druggist. He first studied medicine at the PersianSyriac Medical School of Gandeshapur, and then passed several years in perfecting himself in the Greek language. After this he went to Basra to study Arabic, where he entered the service of the physician to the Caliph E1 Mamun, who appointed him superintendent of his "House of Wisdom," a kind of libraryacademy. Here he produced an amazing quantity of translations of the books of Galen, and of other Greek medical and philosophical authors. He also made long journeys through 
Mesopotamia, Syria, Palestine and Egypt in order to find Greek scientific manuscripts during succeeding caliphates.

Under the Caliph El Mutawakkil, A.D. 847 to 861, Hunain reached the summit of his prosperity as a medical practitioner and translator, but the envy of his fellow Christian colleagues lost him his favour with the Moslem potentate. At one time the Caliph ordered Hunain to prepare a poison for an inconvenient subject, and on his refusal imprisoned him for a year. When he was again brought before the Caliph and asked why he refused, even under threat of death, Hunain replied: "Two things, my religion and my profession! My religion commands us to do good, even to our enemies, so much more to our friends, and my profession forbids us to do harm to our kindred, as it is instituted for the benefit and the welfare of the human race, and God imposes on physicians the oath not to compose mortiferous remedies.'

A few years later, Hunain was denounced to the Moslem Caliph as a heretic in his Nestorian faith, so he was made to spit on an image of the Virgin and handed over to the head of the Church at Baghdad, by whom he was imprisoned and flogged from time to time, while the Caliph confiscated his goods. But it was the loss of his books that affected him most: he says "I had lost all the books which I had gradually collected during the course of the whole of my adult life in all the lands in which I had travelled, all of which books I lost at one blow."

After four months of imprisonment, Hunain regained the favour of the Caliph by a successful cure, his fortunes were restored and his enemies disgraced. Henceforth, he was left in peace to continue his translation work for a period of 20 years, being assisted materially by his nephew Hubaish, and by numerous pupils.

Hunain died about A.D. 877 at the age of 68 years. He appears to have passed a pleasant life. He rode every day, came back and had a Turkish bath, drank a cup of wine and ate a cake. He then slept a little, after which he dined on a chicken and a loaf of bread. He limited himself, as regards alcohol, to half a gallon of old wine daily. It is interesting to note that he wrote a book "On the Diet of Old Men."

\section{Hunain's Translations}

Prof. E. G. Browne states that Hunain translated the Greek into Syrian, while his nephew Hubaish translated the Syriac into Arabic, which Hunain then revised; but sometimes he translated direct from Greek into Arabic. Hunain states that when he found manuscripts defective he made every endeavour to obtain other 
copies for the purpose of collating the best possible text, in fact his philological methods were quite modern.

The number of his translations was very large. It included 95 books of Galen, many of the works of Hippocrates, of Paulus Aegineta, of Oribasius, of Dioscorides, and of Aristotle.

\section{Hunain as an Author}

More than 100 different works have been ascribed to Hunain, no doubt many erroneously. Hunain's original books naturally reflect the works of the Greek physicians, the translation of which constituted the essential activity of his whole laborious life. The book which made him famous in Mediaeval Europe was his introduction to the "Ars Parva Galeni," which was translated into Latin under the title "Isagoge Johannitii" and printed at Leipzig in 1497. Other books treat of diet, fever, the pulse and the urine, while another is on veterinary medicine.

However, the greatest and most famous book Hunain wrote is "The Ten Treatises on the Eye." Meyerhof has written an interesting introduction, from which the present article is compiled.

The first treatise gives the anatomy of the eye according to Galen, with all his mistakes which were dominant for 1,400 years. Thus the crystalline lens, which in Arabic is translated as " the ice-like humour," is placed in the middle of the eyeball and is made the principal organ of vision. The other tunics and humours of the eye are supposed to be for the purpose of protecting and nourishing the lens. The retina is recognised as the terminal extension of the optic nerve but its true function is unknown. The six muscles of the eye are well described, but to them is added a retractor bulbi, a muscle which only occurs in certain mammals. This mistake was the obvious result of the dissection of animals instead of the human body.

It is interesting to remember that all these errors were repeated by the great anatomist Vesalius, in the middle of the sixteenth century. It was about that time that Falloppio proved the non-existence of the retractor bulbi, while the real position of the lens was not described until the year 1600 by Fabricius ab Aquapendente. It was not until 1604 that Kepler found out the true nature of the lens and retina.

The second treatise deals with the description of the brain on the lines of Galen.

The third treatise describes the optic nerves, the visual spirit and vision itself. The visual spirit " is a kind of animal spirit which. enters the two anterior ventricles of the brain, where it is thoroughly matured, subtilised, purified and extracted and arranged, . . . . . according to the nature of the brain." 
The fourth treatise is an extract from various books of Galen on drugs, treatment, aetiology and symptomatology.

The fifth treatise is a theoretical exposition of hypothetical diseases of the membranes and humours of the eye.

The sixth treatise is particularly interesting because it has no model in Galen's existing works. It probably follows his lost treatise "The Diagnosis of Eye-diseases." It begins with the symptoms of conjunctival diseases. An entirely new fact here comes to light that pannus was not observed for the first time by the Arabs but was known to the Greeks under the name of kirsophthalmia.

The seventh and eighth treatises deal with simple remedies.

The ninth treatise describes the operation of couching a cataract.

The tenth treatise contains a number of prescriptions for ophthalmic remedies. It has the following preface by Hunain :"During more than thirty years I had composed different treatises concerning the eye in which I pursued divergent aims about which I was questioned by several people one after another. Then one of my friends (his nephew Hubaish), collected those treatises and asked me to give them titles after having united them all in one volume in a convenient manner and so I did this."

Hunain ends his volume with the satisfying sentence :- "This is a book containing all the knowledge necessary for those who wish to treat the diseases occurring in the eye in a reasonable manner."

It is difficult to compute the days and nights of labour which Meverhof must have spent in preparing this book for publication, and as difficult to estimate the heavy private expenditure which it must have involved. However, most of us can dimly appreciate the scholarship required for work of this kind, and congratulate Ophthalmology on having so erudite a disciple.

\section{MARGINAL DEGENERATION OF THE CORNEA}

BY

\section{J. H. DOgGaRT}

LONDON

MARGINAL degeneration of the cornea is a rare, bilateral condition, twice as common in men as in women, with opacity and vascularisation of the peripheral zone of the cornea as its earliest signs. The epithelium remains intact, but there follows a progressive thinning of the cornea at the expense of Bowman's membrane and the anterior layers of the substantia propria, so that a gutter is formed. 